Клехо Олена

викладач інформатики КЗВО «Луцький педагогічний коледж», Україна,

м. Луцьк, Україна

ORCID: 0000-0002-2270-0898

e-mail: olenakov102@gmail.com

Четверикова Тетяна

викладач інформатики

КЗВО «Луцький педагогічний коледж»,

м. Луцьк, Україна

ORCID: 0000-0002-2318-635X

e-mail:chetv_@ukr.net

\title{
ОСОБЛИВОСТІ ЗАПРОВАДЖЕННЯ ТЕХНОЛОГІЇ ЗМІШАНОГО НАВЧАННЯ У ПЕДАГОГІЧНОМУ КОЛЕДЖІ
}

Анотація. Стаття присвячена опису впровадження в освітній процес змішаного навчання у комунальному закладі вищої освіти «Луцький педагогічний коледж», яка реалізована засобами хмарної платформи Google Workspace. Окреслено основні напрями використання такої технології у закладі освіти, наведено приклади сервісів, програмного забезпечення, інтерактивних методів, описано методику їх використання в освітньому процесі. Відзначено переваги цієї освітньої технології. Навчання стає більш відкритим, студенти вчаться керувати своєю навчальною діяльністю. Змішане навчання дає можливість розвивати у студентів свідомість, самодисциплінованість, самостійність, творче та креативне мислення, сприяє підвищенню інформаційно-цифрової компетентності учасників освітнього процесу.

Висвітлено суть, особливості організації та змісту змішаного навчання. Для організації такого навчання заклад освіти перейшов на використання сучасної освітньої платформи, яка сприятиме підвищенню якості підготовки студентів, розвитку самостійної творчої діяльності, стимулюватиме одержання додаткових знань та їх закріплення, що забезпечить підготовку конкурентоспроможних фахівців для ринку праці.

У роботі використано методи наукового дослідження: теоретичні методи - вивчення, аналіз, систематизація, порівняння та узагальнення наукової літератури 3 проблеми дослідження; емпіричні методи спостереження за педагогічним процесом, педагогічний експеримент; статистичні методи - математичне опрацювання отриманих даних, логічний підхід, графічне моделювання.

(С) Клехо О.,

Четверикова Т., 2021 
Авторські дослідження грунтуються на організації освітнього процесу Луцького педагогічного коледжу і є продовженням вивчення питання підготовки майбутніх педагогів засобами хмарних технологій.

Ключові слова: заклад вищої освіти (ЗВО), цифрова компетентність, інформаційні технології, змішане навчання, онлайн-навчання, освітній процес.

Постановка проблеми. Реформування освіти та ті зміни, що відбуваються в сучасному суспільстві, вносять корективи у методи та способи подачі матеріалу. Одним з перспективних і необхідних напрямів розвитку навчання в світі, особливо в умовах пандемії, вважається змішане навчання.

Ситуація, що склалася в Україні через епідемію коронавірусу, спонукала заклади вищої освіти шукати ефективні й дієві механізми та інструменти для відновлення освітнього процесу під час карантинних обмежень, забезпечити організацію нового навчального року в цих умовах. У країнах Заходу давно розвивається система змішаної освіти, коли навчання відбувається і в аудиторіях, і дистанційно - онлайн. Проте змішане навчання, а особливо та частина, що відбувається дистанційно, вимагає нових підходів, інших вимог до викладацького складу, до методики викладання і розробки навчального контенту, використання масових сучасних безкоштовних освітніх платформ.

Аналіз останніх досліджень 3 проблеми. Вчені Стенфордського університету здійснили аналіз близько тисячі експериментальних даних, які $\epsilon$ результатами порівняльних досліджень традиційного, онлайн та змішаного навчання. У результаті з'ясовано, що у період з 1996-2008 pp. онлайн-навчання не мало переваг над традиційним, тоді як змішане навчання виявилось помітно ефективнішим. Тож дослідження стало приводом до більш оптимістичних прогнозів для застосування змішаного навчання. Оскільки до розроблюваної методичної системи було залучено технологію мобільного навчання, то очевидним $є$ його впровадження в контексті саме змішаного навчання. Зазвичай освітній процес при змішаному навчанні складається 3 фаз традиційного та електронного навчання, які чергуються (Кухаренко, 2016).

У зарубіжних публікаціях зустрічається термін «гібридне навчання», що вважається синонімом поняття «змішане навчання», і розуміється як таке, що поєднує навчання віч-на-віч 3 онлайн-навчанням, та є найбільш перспективним підходом для вищої освіти. В. Кухаренко та інші розмежовують ці поняття у такий спосіб: змішане навчання акцентує на суто механічному підході до змішування різних форм навчання, а гібридне являє собою поєднання нової, передової, з використанням можливостей IT технології зі старою технологією і формуванням нового підходу (новації) 3 урахуванням відомих можливостей старої технології (Кухаренко, 2016).

Аналіз досліджень зарубіжних вчених та фахівців зі змішаного навчання (Сікора, 2016; Бугайчук, 2016; Овчарук, 2006) засвідчує, що 


\section{Інноватика у вихованні. Випуск 13.Том 1. 2021.}

функціонально його реалізація може відбуватися в кількох аспектах. Наприклад, в системі змішаного навчання як сукупності елементів, об'єднаних для виконання певних функцій освітнього процесу, на перший план виходять такі аспекти:

інституційний;

технологічний (в тому числі в аспекті управління);

навчально-методичний.

Перший передбачає організацію стратегії електронного навчання в інтеграції із класно-урочним навчанням. Головним напрямом цієї стратегії $\epsilon$ уявлення про те, що електронне навчання - це нова парадигма освітніх систем.

Переваги електронного навчання як технології навчання:

задовольняє потреби учасників освітнього процесу, які живуть в цифровому світі;

виступає каталізатором педагогічних нововведень;

стимулює обмін інформацією та поліпшує співпрацю між учасниками освітнього процесу;

спрощує доступ до освітніх баз даних різним категоріям школярів (Прокопчук, 2020).

Технологічний аспект реалізації електронного навчання містить систему управління навчанням (LMS - Learning Management System), яка може бути реалізованою через різні програмні оболонки або платформи на кшталт Moodle (Кухаренко, 2016). Фахівці зі змішаного навчання вказують на дві моделі надання доступу до освітніх ресурсів - в традиційному розумінні та із залученням хмарних технологій. Традиційні LMS надають доступ до освітнього процесу через підключення учасників до матеріалів, форумів тощо. Причому вважається, що соціальні мережі як найбільш доступні засоби спілкування людей в мережі Інтернет, значно розширюють межі виконання спільних проектів і роблять процес навчання більш соціальним. Саме тому, реалізовано досвід (наприклад, в США та в ряді європейських держав) із інтеграції LMS в популярні соціальні сервіси (Костиря, 2020). Друга модель пов'язана із залученням до освітніх систем хмарних технологій. На «хмарі» розташовують спеціально організовані компаніями Google та Microsoft сервіси - G Suite for Education (до 2016 року була інша назва - «Google Apps for Education»), ще пізніше - Google Workspace. Вказані сервіси пропонують учасникам освітнього процесу аналогічні інструменти, які надає автономна LMS. Крім цього хмарні платформи дистанційної освіти дають можливість реалізувати мобільне навчання - електронне навчання на базі мобільної технології (Осадча, 2016).

Мета статті - розглянути впровадження змішаного навчання в освітній процес закладу освіти та ознайомлення i використання можливостей сервісів для реалізації завдань такого навчання задля підвищення якості підготовки студентів, розвитку самостійної творчої діяльності, стимулювання одержання додаткових знань та їх засвоєння. 


\section{Інноватика у вихованні. Випуск 13.Том 1. 2021.}

Виклад основного матеріалу дослідження. Змішане навчання освітній процес, коли відбувається поєднання онлайн навчання, традиційного та самостійного навчання. Мається на увазі не просто використання сучасних інтерактивних технологій на додаток до традиційних, а якісно новий підхід до навчання, що трансформує, а іноді і «перевертає» клас (Овчарук, 2006).

До початку навчального року керівництво закладу освіти поставило за мету запровадити змішане навчання з дотриманням усіх карантинних норм і правил. Але основною проблемою залишався вибір платформи, тобто, реалізація технологічного аспекту змішаного навчання. Проаналізувавши досвід інших закладів, акумулювавши власний, ми обрали Google Workspace як просту й зручну платформу для роботи, усі сервіси якої інтегровано між собою. Цей пакет спеціалізованого хмарного забезпечення економить час і допомагає продуктивніше працювати, а новітні технології штучного інтелекту й пошуку сприяють ефективності в роботі. Працювати можна де завгодно й на будь-яких пристроях, навіть без підключення до Інтернету. Google Workspace можна інтегрувати, розширювати й повністю персоналізувати відповідно до потреб команди і кожного користувача окремо.

3 метою підвищення цифрової грамотності та інформаційної компетентності для викладачів інших дисциплін фахівці 3 інформатики організували і провели низку заходів, Ми з колегами спробували себе у ролі фасилітаторів навчального процесу, оскільки наша роль зводилась більше до мотивації, стимулювання і направлення процесу самостійного пошуку інформації та спільної діяльності учасників заходів.

Згодом ми почали розробляти власний цифровий контент (i продовжуємо працювати над цим питанням), який має важливе значення для впровадження онлайнових та змішаних технологій навчання. Створюємо власний контент, використовуємо контент сторонніх розробників і комбінацію обох. Прийняття відповідних рішень обумовлюється навчальним навантаженням викладачів, наявністю та обсягом фінансування, узгодженістю стороннього контенту 3 освітнім стандартам, програмами та календарно-тематичним планам.

Для успішної реалізації технологічної інфраструктури ми запровадили надійну телекомунікаційну мережу, програмне забезпечення, апаратні засоби.

У процесі роботи ми побачили, що основна відмінність змішаного навчання від звичайної системи - активне використання інформаційних технологій для пошуку матеріалу і отримання нових знань. Так, технології стають повноцінною частиною навчального процесу. Проте йдеться також і про поєднання різних підходів, способів подачі матеріалу, видів роботи. Наприклад, частина інформації розподіляється на групову роботу, частина - на самостійне вивчення, що не залежить від того, відбувається це у класі чи дистанційно. За змішаного навчання несхожою також $\epsilon$ i роль викладачів. Тут вони - фасилітатори освітнього процесу. Тобто, люди, які 


\section{Інноватика у вихованні. Випуск 13.Том 1. 2021.}

організовують колективне обговорення у такий спосіб, аби усі учасники були максимально залучені, а проблеми вирішувалися швидко й ефективно. Тож, основна мета викладачів - не оцінити студентів на екзамені, заліку чи під час семестрових контролів, а активно взаємодіяти 3 ними, відстежувати прогрес та допомагати у разі потреби. Так вчителі перестають бути просто спостерігачами і виконують роль менторів.

Підготовка конкурентоспроможного педагога і справжнього фахівця своєї справи концентрує не тільки теоретичний рівень підготовки, а й формування практичних навиків у результаті організації і проведення різних видів практики. Але провести практику в карантинних умовах без дітей, без доступу до закладів загальної середньої освіти здавалося б неможливо! Ми шукали вирішення проблеми через застосування методів моделювання конкретної ситуації, дидактичної гри, ділової гри. Активні та інтерактивні методи навчання сприяють розвитку професійних навичок, формують вміння взаємодії з партнерами, викликають позитивні емоції, стимулюють розумову діяльність, розвивають нестандартне мислення (Башкір, 2018). У процесі проведення ділової гри навчання максимально наближається до реальної практичної діяльності, що активізує отримані теоретичні знання, забезпечує формування практичних навичок. Створення проблемних ситуацій - хороша можливість спостерігати індивідуальну реакцію студентів на проблему, шукати різні варіанти іiі вирішення.

Висновки і перспективи подальших розвідок. Впровадження у освітній процес закладу вищої освіти технології змішаного навчання, підвищення рівня цифрової компетентності викладачів і студентів ЗВО на основі аналізу проблемних ситуацій бачення та формулювання педагогічних завдань, знаходження оптимальних способів розв'язання освітніх завдань із максимальним використанням можливостей хмарних технологій.

Перспективними напрямами для наступних досліджень $є$ подальше вивчення i аналіз методик електронного навчання, можливостей соціальних мереж, хмарних обчислень, тематична та змістова розробка курсів, тренінгових занять i розробка методики їх використання в освітньому процесі для викладачів та студентів.

\section{СПИСОК ВИКОРИСТАНИХ ДЖЕРЕЛ}

Теорія та практика змішаного навчання: монографія / Кухаренко В. М. та ін.; Х.: «Міськдрук», НТУ «ХПІ», 2016. 284 с.

Сікора, Я. (2016). Реалізація змішаного навчання у вищому навчальному закладі. В: Науковий вісник Ужгородського університету. серія: «Педагогіка. Сочіальна робота». Вип. 2 (39). СС.236-239.

Бугайчук, К. (2016). Змішане навчання: теоретичний аналіз та стратегія впровадження в освітній процес вищих навчальних закладів. В: Інформаційні технології $і$ засоби навчання: електронне наукове фахове видання. Ін-т інформ. технологій $i$ засобів навчання АПН України, Ун-т 


\section{Інноватика у вихованні. Випуск 13.Том 1. 2021.}

менеджменту освіти АПН Украӥни; гол. ред.: В. Ю. Биков, Том 54. №4. URL: http://journal.iitta.gov.ua/index.php/ittt/article/view/1434/1070. [Дата звернення 15.02.21].

Овчарук, О. (2006). Концептуальні підходи до застосування технологій відкритої освіти та дистанційного навчання у зарубіжних країнах та їх роль у процесах модернізації освіти. Інформаційні технології $i$ засоби навчання, Вип.1. CC.56. URL: :http://journal.iitta.gov.ua/index.php/itlt/article/view/292/278. [Дата звернення 11.02.21].

Прокопчук, М. (2020). Із досвіду впровадження змішаного навчання при вивченні англійської мови за професійним спрямуванням. Міжнародний науковий журнал «Інтернаука». Вип. 6. CC.28-32. URL: https://www.inter-nauka.com/ uploads/public/15888486954161.pdf. [Дата звернення 11.02.2021].

Сайт «Главком». Змішане навчання: куди бігти і що робити. Інна Костиря. URL: https://glavcom.ua/columns/kostyrya/zmishane-navchannyakudi-bigti-i-shcho-robiti-703977.html [Дата звернення 11.02.21].

Осадча, К., Осадчий, В., Круглик, В. та Наумук, І. (2020). Змішане навчання як форма сучасної підготовки майбутніх фахівців професійної освіти. Педагогіка формування творчої особистості у вищій $i$ загальноосвітній школах, Вип.71. СC.187-192. URL: http: //pedagogyjournal.kpu.zp.ua/archive/2020/71/part_2/37.pdf [Дата звернення 11.02.21].

Башкір, О. (2018). Активні й інтерактивні методи навчання у вищій школі. Педагогіка і психологія, № 60. СС. 33-44. Харківський національний педагогічний університет імені Г.C. Сковороди. URL: http://journals.hnpu.edu.ua/index.php/pedagogy/article/view/1656 [Дата звернення 15.02.21].

Змішане навчання: сутність та переваги у сучасному світі. Блог EdEra. Jared Stein and Charles Essentials for Blended Learning A StandardsBased Guide. Режим доступу : http://blog.ed-era.com/blended-learning-sutpierievaghi-ta-uspishni-prikladi/ [Дата звернення 15.02.21].

\section{REFERENCES}

Kukharenko, V. et al (2016). Teoriia ta praktyka zmishanoho navchannia [Theory and practice of blended learning]. Kh.: "Miskdruk", NTU "KhPI" [in Ukrainian].

Sikora, Ya. (2016). Realizatsiia zmishanoho navchannia u vyshchomu navchalnomu zakladi (2016). [Implementation of blended learning in higher education]. V: Naukovyi visnyk Uzhhorodskoho universytetu. seriia: «Pedahohika. Sotsialna robota». Vyp, 2(39), SS. $236-239$ [in Ukrainian].

Buhaichuk, K. (2016). Zmishane navchannia: teoretychnyi analiz ta stratehiia vprovadzhennia $\mathrm{v}$ osvitnii protses vyshchykh navchalnykh zakladiv [Blended learning: theoretical analysis and strategy of introduction of higher educational institutions into the educational process]. Informatsiini tekhnolohii $i$ zasoby navchannia: elektronne naukove fakhove vydannia. In-t inform. 


\section{Інноватика у вихованні. Випуск 13.Том 1. 2021.}

tekhnolohii i zasobiv navchannia APN Ukrainy, Un-t menedzhmentu osvity APN Ukrainy; hol. red.: V.Yu.Bykov . URL: http://journal.iitta.gov.ua/index.php/ittl/article/view/1434/1070 [Data zvernennia 15.02.21]. [in Ukrainian].

Ovcharuk, O. (2006). Kontseptualni pidkhody do zastosuvannia tekhnolohii vidkrytoi osvity ta dystantsiinoho navchannia u zarubizhnykh krainakh ta yikh rol u protsesakh modernizatsii osvity [Conceptual approaches to the application of technologies of open education and distance learning in foreign countries and their role in the processes of modernization of education Information technologies and teaching aids]. Informatsiini tekhnolohii $i$ zasoby navchannia. $\quad$ Vyp. $1, \quad 56 . \quad$ URL: http://journal.iitta.gov.ua/index.php/itlt/article/view/292/278. [Data zvernennia 15.02.2021]. [in Ukrainian].

Prokopchuk, M. (2020). Iz dosvidu vprovadzhennia zmishanoho navchannia pry vyvchenni anhliiskoi movy za profesiinym spriamuvanniam [From the experience of implementing blended learning in the study of English for professional purposes]. Mizhnarodnyi naukovyi zhurnal "Internauka". Prectice, 6, 28-32. URL: https://www.inter-nauka.com/ uploads/public/15888486954161.pdf. [Data zvernennia 15.02.21]. [in Ukrainian].

Sait "Hlavkom" Zmishane navchannia: kudy bihty i shcho robyty [Glavkom website. Blended learning: where to run and what to do]. glavcom.ua. URL: https://glavcom.ua/columns/kostyrya/zmishane-navchannya-kudi-bigti-ishcho-robiti-703977.html. [Data zvernennia 15.02.21]. [in Ukrainian].

Osadcha, K., Osadchyi, V., Kruhlyk, M., Naumuk, I. (2020). Zmishane navchannia yak forma suchasnoi pidhotovky maibutnikh fakhivtsiv profesiinoi osvity [Blended learning as a form of modern training of future professionals in vocational education]. V: Pedahohika formuvannia tvorchoi osobystosti u vyshchii i zahalnoosvitnii shkolakh. Vyp. 71, 187-192. URL: http://pedagogyjournal.kpu.zp.ua/archive/2020/71/part_2/37.pdf. [Data zvernennia 15.02.21]. [in Ukrainian].

Bashkir, O. (2018). Aktyvni y interaktyvni metody navchannia u vyshchii shkoli [Active and interactive higher school training methods]. Pedahohika i psykholohiia. Kharkivskyi natsionalnyi pedahohichnyi universytet imeni H.S. Skovorody. No 60.65 S. 33-44. URL: http://journals.hnpu.edu.ua/index.php/pedagogy/article/view/1656(accessed 11.02.2021). [Data zvernennia 15.02.21]. [in Ukrainian].

Bloh EdEra "Zmishane navchannia: sutnist ta perevahy u suchasnomu sviti" [EdEra Blog Blended learning: essence and advantages in the modern world]. blog.ed-era.com. URL: http://blog.ed-era.com/blended-learning-sutpierievaghi-ta-uspishni-prikladi [Data zvernennia 15.02.21]. [in Ukrainian]. 


\section{PECULIARITIES OF IMPLEMENTATION BLENDED LEARNING TECHNOLOGY AT PEDAGOGICAL COLLEGE}

Olena Klekho

Computer Science teacher, Municipal Institution of Higher Education «Lutsk Pedagogical College» of Volyn Regional Council, Lutsk, Ukraine ORCID: 0000-0002-2270-0898 email:olenakov102@gmail.com

Tetyana Chetverykova

Computer Science teacher, Municipal Institution of Higher Education «Lutsk Pedagogical College» of Volyn Regional Council, Lutsk, Ukraine ORCID: 0000-0002-2318-635X email: chetv_@ukr.net

Abstract. The article is devoted to the description of the introduction of blended learning in the educational process at the communal institution of higher education "Lutsk Pedagogical College", which is implemented by means of a cloud platform Google Workspace. The main directions of using this technology in the institution are outlined, examples of services, software, interactive methods are given, the method of their use in the educational process is described. The advantages of this educational technology are noted. Learning becomes more accessed, students have the opportunity to learn to manage their learning activities. Blended learning provides an opportunity to develop students' consciousness, self-discipline, independence, creative and creative thinking, helps to increase the information and digital competence of participants in the educational process.

The essence, features of the organization and content of blended learning are highlighted. The educational institution has switched to the use of a modern educational platform for the organization of such training, which will improve the quality of student training, develop independent creative activity, stimulate additional knowledge and consolidate it, which allows to train competitive professionals for the labor market.

The methods of scientific research are used in the work: theoretical methods: study, analysis, systematization, comparison and generalization of scientific literature on the research problem, empirical methods: observation of pedagogical process; pedagogical experiment; statistical methods: mathematical processing of the received data, logical approach graphic modeling.

The author's research is based on the organization of the educational process of Lutsk Pedagogical College and is a continuation of the study of the issue of training future teachers by means of cloud technologies.

Keywords: higher education institution (HEI), digital competence, information technologies, blended learning, online learning, educational process.

Стаття надійшла до редакиії 25.02.2021 p. 